\title{
Consumers' Willingness to Pay for Basic Goods and Services Before and During Pandemic Covid-19 in Malaysia
}

\section{Zuroni Md Jusoh, Norzalina Zainudin, Laily Paim, Nizam Ahmat}

To Link this Article: http://dx.doi.org/10.6007/IJARBSS/v11-i11/11648

DOI:10.6007/IJARBSS/v11-i11/11648

Received: 13 September 2021, Revised: 16 October 2021, Accepted: 30 October 2021

Published Online: 19 November 2021

In-Text Citation: (Jusoh et al., 2021)

To Cite this Article: Jusoh, Z. M., Zainudin, N., Paim, L., \& Ahmat, N. (2021). Consumers' Willingness to Pay for Basic Goods and Services Before and During Pandemic Covid-19 in Malaysia. International Journal of Academic Research in Business and Social Sciences, 11(11), 1599-1609.

\section{Copyright: @ 2021 The Author(s)}

Published by Human Resource Management Academic Research Society (www.hrmars.com)

This article is published under the Creative Commons Attribution (CC BY 4.0) license. Anyone may reproduce, distribute, translate and create derivative works of this article (for both commercial and non0-commercial purposes), subject to full attribution to the original publication and authors. The full terms of this license may be seen at: http://creativecommons.org/licences/by/4.0/legalcode

Vol. 11, No. 11, 2021, Pg. $1599-1609$

Full Terms \& Conditions of access and use can be found at http://hrmars.com/index.php/pages/detail/publication-ethics 


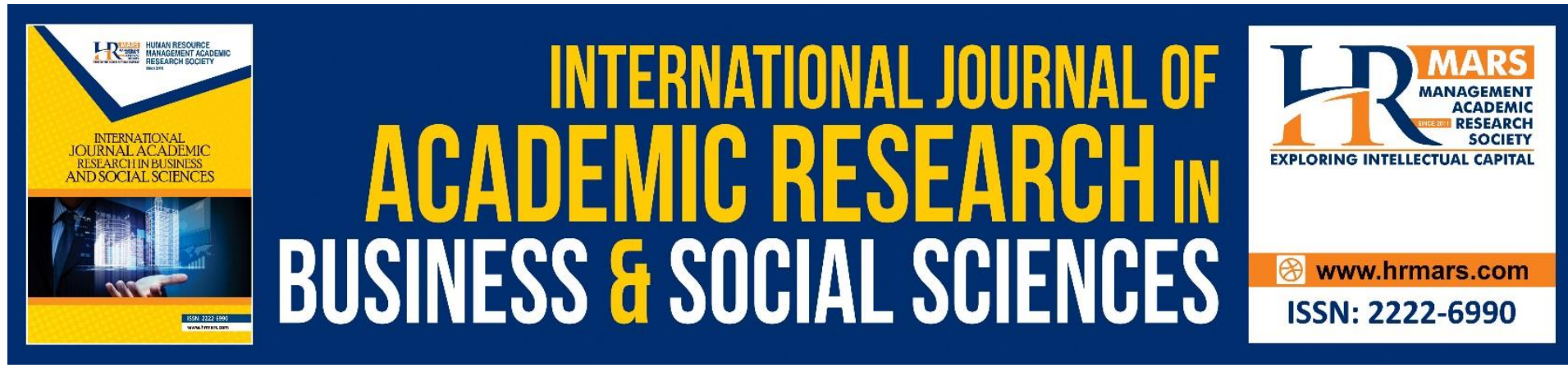

\title{
Consumers' Willingness to Pay for Basic Goods and Services Before and During Pandemic Covid- 19 in Malaysia
}

\author{
Zuroni Md Jusoh, Norzalina Zainudin, Laily Paim \\ Sustainable Consumption Research Excellence Centre, Faculty of Human Ecology, \\ University Putra Malaysia, 43400 Serdang, Selangor. \\ Nizam Ahmat \\ Department of Economics, Faculty of Business, Economics and Social Development, \\ University of Malaysia Terengganu, 21030 Kuala Nerus, Terengganu.
}

Email: zuroni@upm.edu.my

\begin{abstract}
In the early of 2020, Malaysia had been affected by the outbreak of Coronavirus Disease 2019 (COVID-19). With regards to what people are buying, Malaysians reported that they spend more on items with longer shelf life than they would usually do. The aim of this study to analyse the consumers' willingness to pay (WTP) for goods and services before and during pandemic COVID-19. A total of 481 respondents involved in this study through convenience sampling method via self-administered questionnaires were distributed. Collected data were then analysed using Statistical Package for Social Sciences (SPSS) version 22 and EViews version 10. The mean WTP that consumers willing to pay for face mask was MYR1.92 (21.9\%) during COVID-19 as compared before COVID-19 at MYR1.50. Meanwhile, Logit estimation result shows all of the predictor variables (ScoreDif, Age, Income1, Income2, Location and Family size) of WTP for higher prices were significant. In conclusion, the consumers were WTP more for basic goods and services during COVID-19 outbreak as compared before COVID-19 outbreak. Through this study, Malaysian consumers could get to know more about how much they are WTP for basic goods and services before and during COVID-19 outbreak.
\end{abstract}

Keywords: Consumers, Willingness to Pay, Basic Needs, COVID-19, Behaviour

\section{Introduction}

COVID-19 is a disease caused by a virus strain that began spreading among people since December 2019 in China. In the early of 2020, Malaysia had been affected by the outbreak of Coronavirus Disease 2019 (COVID-19), alongside the rest of the world, thus classifying it as a worldwide pandemic. This COVID-19 pandemic gives negative impact to economics, health and industries. Recently, the continued rising spread of COVID-19 in the world threatens demand and supply for basic goods and services such as food, face mask, hand sanitizer, other health products (Wang et al., 2020). This contributes to the increase in prices and Malaysia's GDP fell by $17.1 \%$ in the second quarter of 2020 (DOSM, 2020). 
With regards to what people are buying, Malaysians reported that they spend more on items with longer shelf life than they would usually do. Basically, during times of distress or anxiety, basic needs are prioritised and consumers shift their behaviour to focus on "panic buying" of non-durable goods which aid in survival, including food, water and medication. Thus, this study can help us predict the change of consumer consumption and understand more about consumer WTP behaviour in an emergency COVID-19. Although there exist numerous previous studies of consumer behaviour in normal circumstances (Wang et al., 2018; Gao et al. 2019), no such studies exist about consumer purchasing behaviour and preferences in emergencies. Consumer behaviour and preference are quite special and different from the common scenario (Kurihara et al., 2012).

Thus, this research is primarily to analyse the consumers' willingness to purchase or to pay (WTP) for the basic goods and services before and during pandemic COVID-19 in Malaysia. Specifically, this study also to explore the socio-economic background (gender, ethnic, education level, occupation, income) among consumers, to evaluate the mean score of WTP for basic goods and services before and during COVID-19, to investigate the mean of WTP premium for face mask during COVID-19 and to analysis the impact of socio-economic factors and behaviour response to higher level on WTP for basic goods and services before and during COVID-19.

\section{Literature Review \\ Maslow's Hierarchy of Needs Model}

Consumer behaviour during the COVID-19 period has demonstrated a shift in consumption of basic needs and non-durable items, prioritising the base layer of Maslow's Hierarchy of Needs (Loxton, 2020). Maslow's Hierarchy of Needs Model might be used to classify purchases as "needs" versus "wants." Lester (2013) demonstrates the classification of consumer behaviours based on a pyramidal hierarchy, which classifications are considered most vital to human survival. These were five classifications, starting from the base of the pyramid include, (1) physiological necessities, (2) safety, consumer protection and wellbeing, (3) love and belonging, (4) self-esteem, and (5) self-actualisation or personal growth. In line with the hierarchy, consumers during crises tend to focus on satisfying basic physiological needs first, before moving onto higher levels and towards more luxury discretionary behaviours (Forbes, 2017). Whilst Maslow's hierarchy is scaled according to the economic markets it is applied in, both advanced and emerging economies demonstrate similar shifts in consumer behaviour (Samli, 2012). Maslow's model provides a valuable platform for analysing consumer behaviour during periods of stress or anxiety, generated through emotions or more tangible stresses, such as a global pandemic (Loxton, 2020).

The second tier of Maslow's hierarchy, safety needs, is applied to the COVID-19 period as outlining an individual's sense of security and protection against the outbreak of the virus (Siddiqui, 2020). It includes an individuals' need for goods which might increase their feeling of security, including hand sanitisers, masks, disinfectant and other sanitary items. Consumer consumption in United States has shifted to reflect this need, as with consumption of medical necessities including disposable gloves increasing by 670\% in March 2020 in a year-on-year basis (Jones, 2020). Additional supplies including cough medicine increased by $535 \%$, toilet paper $190 \%$, vitamins $166 \%$ and pain relievers $99 \%$ (Russell, 2020). The commonality between all products is the ability or perception that they might safeguard consumers against the virus. 
As expected, consumers have shifted consumption to fulfil more essential and practical needs at the bottom of Maslow's pyramid before achieving self-fulfilment needs.

\section{Willingness To Pay (WTP)}

Many consumers buy unusually large amounts of products to avoid possible future shortage or rising prices (Su, 2010; Shou et al., 2013). Most respondents were willing to pay a high premium but less than $100 \%$ for fresh food during COVID-19 and it makes sense that most respondents are likely to pay a high premium for fresh food reserves (Wang et al., 2020). In addition, mean of WTP premium for fresh food was $60.47 \%$ higher during COVID-19 (Wang et al., 2020). The number of respondents increased when their WTP a high premium but less than $100 \%$, which is consistent with previous study about consumers' preferences for green or sustainable food (Yu et al., 2014; Gao et al., 2016b).

\section{Methods}

A cross-sectional study was carried out based on a survey. Accordingly, this study was conducted quantitatively by using a self-administered questionnaire, which consisted of two sections: Sections A, and B. Consecutively, Section A deliberates the socioeconomic background aspect using open and closed-ended questions, Next, Part B deals with WTP for basic goods and services with a scale of 1 to 5 to discuss specific aspects in which scale 1 means "strongly disagree" and scale 5 indicates "strongly agree".

The questionnaire was pretested among 20 respondents, and all the necessary adjustments revealed during this process were operated by rephrasing several questions and introducing new answer choices. The questionnaire was disseminated through the social media channels and by email. The scope of the survey and objectives of the research were made available to all participants. The participants gave consent and voluntarily joined the study.

The survey was applied one month after the restrictions imposed on free movement of the population were enforced by the Malaysian government. In this study, data collection was carried out in Malaysia by using convenience sampling. In general, the minimum sample size for a population of 1 million at 95 per cent confidence level and 5 per cent margin error is 384 as suggested by Dillman (2000), whereas Needham and Vaske (2008) have suggested for a sample of 400. Pallant (2013) has also recommended a larger sample size for social science studies to make allowances for the possibility of rejection by potential respondents or nonresponse items. However, the target sample in this study was 481 respondents. Selfadministrated questionnaires were distributed through the social media channels and email by using Google Form starting April 2020 until June 2020.

Then, collected data were analysed by using Statistical Packages for Social Sciences (SPSS) version 22 via descriptive analysis across the respondents' profile and inferential analyses (Paired sample T-test \& Independent T-test) and EViews version 10 via Logistic model to achieve the study objectives.

Logistic model has the form as follows: In $\left(\mathrm{P}_{\mathrm{i}} / 1-\mathrm{P}_{\mathrm{i}}\right)=\alpha_{\mathrm{i}}+\beta_{\mathrm{ij}} \mathrm{X}_{\mathrm{ij}}+\mu_{\mathrm{i}}$ (equation 1$)$ where $\mathrm{Pi}$ probability of the dependent variable $(Y)$ take value 1 for respondent agree to pay higher price of good and services during COVID-19 verse value 0 for disagree respondent, $\alpha_{i}$ is intercept, $B_{i j}$ is the regression parameter $i$ of variables $j, X_{i j}$ refer to set of independent variables of 
respondent $i$ for variables $\mathrm{j}$ and $\mathrm{u}_{\mathrm{i}}$ is error term. So we change $z_{i}=\alpha_{i}+\beta_{i j} x_{i j}+\mu_{i}$ Taking antilog both sides in equation 1 and solve for $\mathrm{Pi}$ to get expression such as $\mathrm{Pi}=\exp \left(\mathrm{z}_{i}\right) /\left(1+\exp \left(\mathrm{z}_{i}\right)\right.$ represent the nonlinear relationships between $Y$ and explainable variables $\left(X_{i j}\right)$ such as differences response before and during COVID-19, income1 (income $<$ MYR3001; otherwise = 0 ), income2 (MYR3001 $\leq$ Monthly personal income $\leq$ MYR6000; otherwise $=0$ ), family size (Family size $\leq 5=1$; otherwise $=0$ ), age (age $>35=1$; otherwise $=0$ ) and location (rural area = 1 ; otherwise $=0$ ). The method used to estimate parameter for $\alpha_{i}$ and $\beta_{i j}$ are by using the maximum likelihood (ML) approach. More meaningful explanation of logistic estimation by using marginal effect instead of using the odds ratio for predictors variables. According to Sankar Kumar (2015) marginal effect of logistic model can be calculated as follow; $\frac{d P_{i}}{d X_{i}}=\frac{d P_{i}}{d z_{i}}$ * $\frac{d z_{i}}{d x_{i}}$ where $\frac{d P_{i}}{d x_{i}}$ shows change in $\mathrm{Pi}$ as a results of one point change in independent variable, $\frac{d P_{i}}{d z_{i}}=\frac{e^{-\widehat{\alpha}-\widehat{\beta} \bar{x}_{i}}}{\left(1+e^{\left.-\widehat{\alpha}-\hat{\beta} \bar{x}_{i}\right)^{2}}\right.}$ and $\frac{d z_{i}}{d x_{i}}=\beta_{i}$. This formula will be used by author to find out change in $\mathrm{Pi}$ as a results changes one point in independent variables.

\section{Findings and Discussion Respondents' Background}

From the total respondents ( $\mathrm{N}=481), 62.8 \%$ were female and $37.2 \%$ were male. Most of the respondents were Malays (80.7\%) followed by Indian and Others (native Sabah and Sarawak) $6.9 \%$ respectively and lowest is Chinese (5.6\%). For the category of respondents, $61.8 \%$ are member of household followed by spouse (19.3\%) and head of household (18.9\%). Most of the respondents are educated Bachelor (45.1\%) followed by Higher education (38.5\%) and 8.1\% respectively for Master/PhD and Upper Secondary education and below.

The occupation showed that most of the respondents were worked in private sector $(32.2 \%)$ followed student $(29.9 \%)$, government servant $(22.9 \%)$, business or self-employed $(7.3 \%)$, housewife $(5.6 \%)$ and others $2.1 \%$ (pension and not worked). Most of the respondents were earning income level below and equal MYR3000 (64.5\%), followed by MYR3001 till MYR6000 $(23.5 \%)$ and more than MYR6000 (12\%). 63\% of the respondents stayed in urban area and $37 \%$ stayed in rural area. The breakdown of respondents by regional area showed the Centre region (Selangor, Perak, Kuala Lumpur and Putrajaya) is $38.3 \%$, the Southern region (Johor, Malacca and Negeri Sembilan) is $31.6 \%$, the Eastern region (Kelantan, Terengganu and Pahang) $18.5 \%$, the Northern region (Pulau Pinang, Kedah and Perlis) is $7.8 \%$ while those from another region (Sabah, Sarawak and Labuan) is $11.6 \%$.

\section{Mean of WTP for the Basic Goods and Services Before and During COVID-19}

Table 1 shows the results of the study showing that the respondents are willing to pay more for the increase in prices of basic goods and services during the COVID-19 epidemic (31.3\%). On average, the highest mean is indicated by 'I will still buy food that is good for health even though the cost is high' (4.64). Followed by 'I am willing to buy food because it is more important than other necessities (e.g., clothing)' (4.26). The third highest is 'I am willing to buy food even though the options are limited' (3.83).

Then, amongst the three lowest means are indicated by 'I am willing to pay more for the online purchase of face masks services' (3.15), followed by 'I am willing to pay more for the use of social media tools services (e.g., mobile phones, laptops etc.)' (3.05) and the lowest 
mean 'I am willing to pay more for the use of social media services (e.g., Twitter, Facebook, Instagram, WhatsApp, telegram etc)' (2.97).

Table 1: Mean of WTP for the Basic Goods and Services Before and During COVID-19

\begin{tabular}{|c|c|c|c|c|c|}
\hline No & Statement & $\begin{array}{l}\text { Mean } \\
\text { Before } \\
\text { Covid- } \\
19\end{array}$ & $\begin{array}{l}\text { Mean } \\
\text { During } \\
\text { Covid- } \\
19 \\
\end{array}$ & $\begin{array}{l}\text { Std Dev } \\
\text { Before } \\
\text { Covid- } \\
19\end{array}$ & $\begin{array}{l}\text { Std Dev } \\
\text { During } \\
\text { Covid- } \\
19\end{array}$ \\
\hline$a$ & $\begin{array}{l}\text { I am willing to purchase food even though } \\
\text { the options are limited. }\end{array}$ & 3.67 & 3.83 & 1.51 & 1.46 \\
\hline$b$ & $\begin{array}{l}\text { I am willing to purchase food because it is } \\
\text { more important than other necessities } \\
\text { (e.g. clothes). }\end{array}$ & 4.08 & 4.26 & 1.41 & 1.37 \\
\hline c & $\begin{array}{l}\text { I will purchase food that is good for health } \\
\text { even though the cost is high. }\end{array}$ & 3.823 & 4.64 & 1.43 & 2.02 \\
\hline$d$ & $\begin{array}{l}\text { I will purchase food even though the food } \\
\text { price is expensive. }\end{array}$ & 3.17 & 3.29 & 1.66 & 1.68 \\
\hline e & $\begin{array}{l}\text { I will purchase a face mask even though } \\
\text { the price exceeds the ceiling price (> } \\
\text { RM1.50). }\end{array}$ & 2.59 & 3.48 & 1.73 & 1.63 \\
\hline$f$ & $\begin{array}{l}\text { I will purchase hand sanitizer even though } \\
\text { the price exceeds the ceiling price } \\
\text { (RM10.00 for } 40 \text { millilitres). }\end{array}$ & 2.60 & 3.38 & 2.97 & 1.72 \\
\hline g & $\begin{array}{l}\text { I am willing to pay more for online food } \\
\text { order services (e.g., food panda, food grab } \\
\text { etc). }\end{array}$ & 2.83 & 3.39 & 1.76 & 1.73 \\
\hline $\mathrm{h}$ & $\begin{array}{l}\text { I am willing to pay more for the online } \\
\text { purchase of face masks services. }\end{array}$ & 2.50 & 3.14 & 1.67 & 1.74 \\
\hline $\mathrm{i}$ & $\begin{array}{l}\text { I am willing to pay more for the use of } \\
\text { social media tools services (e.g., mobile } \\
\text { phones, laptops etc.). }\end{array}$ & 2.73 & 3.05 & 1.71 & 1.81 \\
\hline j & $\begin{array}{l}\text { I am willing to pay more for the use of } \\
\text { social media services (e.g., Twitter, } \\
\text { Facebook, Instagram, WhatsApp, telegram } \\
\text { etc). }\end{array}$ & 2.68 & 2.97 & 1.67 & 1.78 \\
\hline k & $\begin{array}{l}\text { I am willing to pay more for the purchase } \\
\text { of health products. }\end{array}$ & 3.46 & 3.68 & 1.61 & 1.54 \\
\hline
\end{tabular}

\section{Willingness to Pay (WTP) Before and During COVID-19}

Willingness to Pay (WTP) refer to measure of monetary value associated with desire value to purchase (Yue et al., 2015). The results by using parametric (column C and D) in the Table 2 clearly shows a significant difference in mean score of WTP for foods $\left(\mathrm{H}_{1}\right)$, face mask $\left(\mathrm{H}_{2}\right)$ and online entertainment $\left(\mathrm{H}_{3}\right)$ and health goods $\left(\mathrm{H}_{4}\right)$ through online order before and during COVID-19 in Malaysia Moreover, by using nonparametric approach (Colum A and B) also support previous test (parametric approach) and give strong evident the are difference in WTP for foods, face mask and hand sanitizer during covid-19 than before COVID-19. In conclusion, all the hypothesis is supported by both approaches, so that these results suggest 
that WTP for foods, face mask, entertainment and health goods through online order was increase during COVID-19 phase than before.

Table 2: Results of Willingness to Pay (WTP) Before and During COVID-19

\begin{tabular}{|c|c|c|c|c|}
\hline Hypothesis & $A^{a}$ & $B^{a}$ & $\mathbf{C}^{\mathbf{b}}$ & $D^{b}$ \\
\hline $\begin{array}{l}\mathrm{H}_{1} \text { : there are differences in the mean / median of } \\
\text { WTP foods through online services. }\end{array}$ & $10.41^{*}$ & $8.15^{*}$ & $11.95^{*}$ & $9.54^{*}$ \\
\hline $\begin{array}{l}\mathrm{H}_{2} \text { : there are differences in the mean / median of } \\
\text { WTP face mask order through online services. }\end{array}$ & $11.36^{*}$ & $9.28 *$ & $13.81^{*}$ & $4.48^{*}$ \\
\hline $\begin{array}{l}\mathrm{H}_{3} \text { : there are differences in the mean / median of } \\
\text { WTP more of online services for entertainment. }\end{array}$ & $7.46^{*}$ & $4.17^{*}$ & $7.91^{*}$ & $3.55^{*}$ \\
\hline $\begin{array}{l}\mathrm{H}_{4} \text { : there are differences in the mean / median of } \\
\text { WTP health goods. }\end{array}$ & $6.75^{*}$ & $3.65^{*}$ & $7.05^{*}$ & $2.86^{*}$ \\
\hline
\end{tabular}

Note: Asterisk ${ }^{*}, \mathrm{a}$ and $\mathrm{b}$ signifies the significance level at $5 \%$, nonparametric- test median differ between two group samples (A-Wilcoxon Rank Test, B- Mann Whitney Test) and parametric approach- test mean score differs between two group samples (C-Paired Sample T-Test, D-Independent T-Test) of testing, respectively.

\section{Distribution of the Experimental Design for Face Mask Price Level}

Out of the 481 respondents, only $74.7 \%$ (360) are willing to pay higher prices of the face mask set by the government while COVID-19 at RM 1.50 per unit. However, 122 (25.3\%) respondents not willing to pay more than selling prices. For further analysis, four levels of prices of face mask (MYR 1.80, MYR 2.25, MYR 2.70 and MYR 3.00) were used in experimental design to estimate WTP in this study take count only 360 respondents. A total of 277 (57.5\%) respondents are willing to pay face mask at price MYR 1.80, 44 (9.1\%) at RM 2.25, 11 (2.3\%) at RM 2.70 and $28(5.8 \%)$ at the highest price of RM 3.00 (Table 3). The Arithmetic mean method employed to estimate WTP using the following formula such as (Sum (FP)) /N where $F$ is frequency and $P$ is the price level and $N$ is the sum of the frequency. Estimation results show that willingness to pay a premium of the respondent approximately is MYR 1.92 or 21.9\% higher per unit face mask. This result similar with Wang et al., 2020 that consumers are willing to pay a premium for fresh food reserves during COVID-19 pandemic, and the mean of the WTP premium is $60.47 \%$ higher for a package of fresh food reserves.

Table 3: Frequency Distribution of the Experimental Design for Face Mask Price Level

\begin{tabular}{lll}
\hline Price Level (MYR) & Frequency & Percentage \\
\hline 1.80 & 277 & 57.5 \\
2.25 & 44 & 9.1 \\
2.70 & 11 & 2.3 \\
3.00 & 28 & 5.8 \\
& & \\
\hline
\end{tabular}

\section{Descriptive Statistics}

Table 4 gives explanations for all variables used and shows the descriptive statistics (mean and standard deviation). Dependent variable represent decision made by the consumer weather they are willing to pay higher prices or not for basic goods and services. About $68.5 \%$ of the respondent are willing to pay higher prices during COVID-19. Total score differs during and before COVID-19 was create as an independent variable to capture consumption patterns 
and behavioural change. Most of the survey respondents are willing to pay 0.363 higher during COVID-19 for basic goods and services. 30.6\% survey respondents are aged more than 35 years old, $50.4 \%$ monthly personal income less than MYR3001, 35.2\% monthly personal income range from MYR3001 to MYR6000, 37\% respondents are lived in rural area and 61\% of the respondents less than 5 person per family.

Table 4: Descriptive Statistics

\begin{tabular}{llll}
\hline Variables & Description & Mean & Std. Dev \\
\hline WTP & Willingness to pay higher prices, Yes =1; No=0 & - & - \\
The score difference & The total scale score for consumption product & 0.36 & 0.58 \\
before and during & and services during COVID-19 minus total & & \\
COVID-19 (ScoreDif) & $\begin{array}{l}\text { scale score before COVID-19 } \\
\text { Respondents age }>35=1 ; \text { otherwise }=0\end{array}$ & 0.31 & 0.46 \\
Age & $\begin{array}{l}\text { Monthly personal income < MYR3001; } 0.50 \\
\text { Income1 } \\
\text { otherwise = } 0\end{array}$ & 0.48 \\
MYR3001 $\leq$ Monthly personal income $\leq 0.35$ & 0.50 \\
Income2 & $\begin{array}{l}\text { MYR6000; otherwise = 0 } \\
\text { Living in rural area = 1; otherwise =0 }\end{array}$ & 0.37 & 0.49 \\
Family size & Family size $\leq 5=1 ;$ otherwise =0 & 0.61 & 0.49 \\
\hline
\end{tabular}

\section{Logit Estimation Results}

The goodness-of-fit test used Hosmer-Lemeshow show that the yields a $X^{2}(10)$ of 10.574 and was insignificant $(p>0.05)$, suggesting that the model was fit with the data. For overall model evaluation suggested by Menard (1995) are on the likelihood ratio and score test only. By using Likelihood ratio $(L R)$ test show that LR statistic $X^{2}(8)=26.641$ and significant $(p<0.05)$ which states that all coefficients of the estimated model are well explaining dependent variable (WTP for higher prices).

According to Table 5, all of the predictor variables of WTP for higher prices were significant at 5\% (ScoreDif, Income1, Location and Family size) and 10\% (Age and Income2) respectively. We can see the odds ratio associated with ScoreDif is 0.5178 which implied that every score increases in ScoreDif the odds of WTP for higher prices are about [(0.5148-1)*100] $48.52 \%$. In term of marginal effect an increase in ScoreDif the probability of WTP of higher prices increase on average by $6.7 \%$. For other explaining variables also have positive effect on WTP for higher prices during COVID-19 on average 3.7\% for Age, Income1 (5.7\%) and Income2 (6.4\%). However, family size and location variables showed inverse (negative) relationship on WTP for higher prices on average $-1.7 \%$ and $-3.2 \%$ respectively. 
Table 5: Logit Estimation Results

\begin{tabular}{llll}
\hline Variables & Coefficient & Wald's $\left.\mathbf{( X}^{2}\right)$ & Marginal Effect \\
\hline $\begin{array}{l}\text { The score difference } \\
\text { before and during }\end{array}$ & 0.5148 & $2.831^{*}$ & 0.067 \\
$\begin{array}{l}\text { Covid-19 (ScoreDif) } \\
\text { Age }\end{array}$ & 0.4650 & $1.921^{* *}$ & 0.037 \\
Income1 & 0.7600 & $2.234^{*}$ & 0.057 \\
Income2 & 0.5943 & $1.872^{* *}$ & 0.064 \\
Location & -0.6525 & $-2.820^{*}$ & -0.017 \\
Family size & -0.4128 & $-2.496^{*}$ & -0.032 \\
Intercept & 1.2997 & $2.787^{*}$ & - \\
& & & \\
\hline Diagnostic & $X^{2}$ & Prob & \\
\hline & & & \\
Likelihood ratio Test & 26.641 & 0.000 & \\
Hosmer-Lemeshow & 10.574 & 0.227 & \\
& & & \\
\hline
\end{tabular}

Note: ${ }^{*}$ Significant at $5 \%$ level. ${ }^{* *}$ Significant at $10 \%$ level.

\section{Conclusion and Implications}

Consumer purchasing behaviour during COVID-19 pandemic poses a demand shock for basic goods and services at market. The consumers were WTP more for basic goods and services during COVID-19 outbreak as compared before COVID-19 outbreak. WTP for foods, face mask and hand sanitizer was increased during COVID-19 phase than before. WTP for foods, face mask, entertainment and health goods through online order was increased during COVID-19 phase than before. Meanwhile, mean of WTP premium that consumers WTP face mask was MYR1.92 (21.9\% higher) per unit. Logit estimation results show all of the predictors variables (ScoreDif, Income1, Income2, Location, Family size and Age) of WTP for higher prices were significant.

Understanding consumer purchasing behaviour is one of the WTP measurement in emergencies can provide important information for governments and policymakers to adjust inventory and response strategies in emergencies. Meanwhile, Malaysian consumers could get to know more about how they are WTP for basic goods and services before and during COVID-19 through this research. The research data was able to provide a direction to the relevant Malaysian governmental bodies and policymakers to response strategies during emergencies time. Thus, the research findings also could contribute a good and reliable dataset to the non-governmental organisations (NGO's).

\section{Acknowledgement}

This study was funded by the Malaysian Consumer and Family Economics Association (MACFEA).

\section{Corresponding Author}

Sustainable Consumption Research Excellence Centre, Faculty of Human Ecology, University Putra Malaysia, 43400 Serdang, Selangor, Malaysia.

Email: zuroni@upm.edu.my 


\section{References}

Department of Statistic Malaysia (DOSM). (2020). Malaysia economy contracts $17.1 \%$ in 2nd quarter, worst slump since 1998 financial crisis.

Dillman, D. A. (2000). Mail and Internet Surveys: The Tailored Design Method. Wiley Publishing.

Forbes, S. L. (2017). Post-disaster consumption: analysis from the 2011 Christchurch earthquake. The International Review of Retail, Distribution and Consumer Research, $27,28-42$.

Gao, Z., Li, C., Bai, J., \& Fu, J. (2016b). Chinese consumer quality perception and preference of sustainable milk. China Economic Review, 100939.

Gao, Z., Yu, X., Li, C., \& Mcfadden, B. R. (2019). The interaction between country of origin and genetically modified orange juice in urban China. Food Quality \& Preference, 71, 475484.

Jones, K. (2020). The Pandemic Economy: What Are Shoppers Buying Online during COVID19? from https://www.visualcapitalist.com/shoppers-buying-online-ecommercecovid-19/ (accessed on 1 June 2021).

Kurihara, S., Maruyama, A., \& Luloff, A. E. (2012). Analysis of consumer behaviour in the Tokyo Metropolitan Area after the Great East Japan earthquake. Journal of Food System Research, 18, 415-426.

Lester, D. (2013). Measuring Maslow's hierarchy of needs. Psychological Reports. Mental \& Physical Health, 113: 15-17.

Loxton, M., Truskett, R., Scarf, B., Sindone, L., Baldry, G. \& Zhao, Y. (2020). Consumer behaviour during crises: preliminary research on how coronavirus has manifested consumer panic buying, herd mentality, changing discretionary spending and the role of the media in influencing behaviour. Journal of Risk and Financial Management, 13, 166, 1-21. doi:10.3390/jrfm13080166

Needham, M. D., \& Vaske, J. (2008). Survey research and analysis: Applications in parks, recreation and human dimensions. Venture Publishing.

Pallant, J. (2013). SPSS survival manual. Allen \& Unwin.

Russell, C. (2020). What retail categories are booming due to coronavirus? Available online: https://www.forbes.com/sites/callyrussell/2020/04/15/what-retail-categories-arebooming-due-to-coronavirus/\#7963c0c42e93

Samli, C. (2012). International Consumer Behaviour in the 21st Century: Impact on Marketing Strategy Development. New York: Springer.

Shou, B., Xiong, H., \& Shen, X. (2013). Consumer panic buying and quota policy under supply disruptions. http://personal.cb.cityu.edu.hk/biyishou/files/MSOMPanic.pdf.

Siddiqui, H. (2020). Fight against COVID-19: All Hands-on Board! Rajnath Singh Urges all Organizations to Assist Civilian Authorities. Available online: https://www.financialexpress.com/defence/fight-againstcovid-19-all-hands-onboard-rajnath-singh-urges-all-organizations-to-assist-civilian-authorities/1916134/

Su, X. (2010). Intertemporal pricing and consumer stockpiling. Operations Research, 58, 11331147.

Wang, E. P., Gao, Z., \& Yan, H. (2018). Improve access to the EU market by identifying French consumer preference for fresh fruit from China. Journal of Integrative Agriculture, 17, 1463-1474.

Wang, E. P., An, N., Gao, Z., Kiprop, E., \& Geng, X. (2020). Consumer food stockpiling behaviour and willingness to pay for food reserves in COVID-19. Food Security, 12,739-747. 
Yu, X., Gao, Z., \& Zeng, Y. (2014). Willingness to pay for the "green food" in China. Food Policy, $45,80-87$.

Yue, C., Zhoa, S., Cummings, C., \& Kuzma, J. (2015). Investigating factors influencing consumer willingness to buy GM foods and nano foods. Journal of Nanoparticle Research, 17, 282. 